nitrogen compounds than of the other groups, ${ }^{1}$ and the basic nitrogen compounds then becoming diamidized, thus materially reducing the amounts of basic nitrogen present.

It is also possible for certain diamino acids to become transformed into diamines, as for example, arginine can be decomposed into urea and ornithine, then into putrescine, while lysine can be converted into cadaverine by the action of certain putrefactive bacteria. The urea that would this be formed is known to be susceptible to the attack of a specific group of bacteria which convert it into ammonium compounds.

These views should not be interpreted to mean that bacteria attack protein at the diamino linkings only; there is much evidence that hydrolysis also takes place all along the line, resulting in the cleavage of amide, diamino and mono-amino acid compounds, all of which doubtless undergo ammonification, although probably at different rates. ${ }^{2}$

It should also be remembered that certain organic nitrogen compounds are readily assimilated by plants, others to a less extent, while still others are incapable of being assimilated. ${ }^{3}$ Therefore, it is possible that the nitrogen compounds belonging to one group may be absorbed by plants to a greater extent than those of other groups. In view of these facts it is apparent that an explanation of the striking differences found in the percentages of nitrogen split off in the different groups in soils, on the one hand, and vegetable proteins, on the other, can only be surmised at the present time. Further investigation on this subject will be undertaken.

HoNOT,UL, HaWAIr.

[Contribution From the Hawail Experiment Station No. i3.]

\title{
THE ORGANIC NITROGEN OF HAWAIIAN SOILS. II. THE EFFECTS OF HEAT ON SOIL NITROGEN.
}

BY W. P. KEZLEXY.

Received November 10, 1913.

Introduction.

It has been observed frequently that soil heating produces notable effects on the growth of crops. With the exception of the studies carried out in the Bureau of Soils, the investigations on this subject have dealt largely with bacteriological and physiological phases of the question. In this connection, Lyon and Bizzel ${ }^{4}$ observed that an increase in the solubility

1 Since this paper was written results have been obtained from ammonification experiments, employing different nitrogenous materials, which strengthen the view that the basic nitrogen group is eliminated from soils at a greater rate than the amide and non-basic nitrogen compounds.

? See Jodidi, Iowa Sta., Research Bull. 9 (1912),

${ }^{3}$ See Hutchinson and Miller, Jour. A gr. Sci., 4, 262-89; also, Schreiner and Skinner,

U. S. D. A., Bur. of Soils, Bull. 77 .

4 Cornell Sta., Bulls. 275 and 326. 
of the organic matter and the amounts of ammonia was produced by steam heating.

Lathrop and Brown ${ }^{1}$ have shown in a study of the soils from the Pennsylvania Experiment Station, that steam heating under pressure brought about increases in the solubility of the nitrogen and the amounts of ammonia present, which increases were roughly proportional to the pressures used.

Schreiner and Lathrop' have shown, from an investigation of two different soils, that a number of organic compounds are split off by steam heating under pressure. It is of interest that all but two of the nitrogen compounds isolated are decomposition products of nucleo-protein. Moreover, certain differences were observed in the nitrogen compounds occurring before heating, although each soil had previously been treated with the same kinds of organic manures; still other compounds occurred only after heating. Of these guanine and arginine were split off from one soil, while adenine was split off from the other.

\section{The Effects of Heat on Hawaiian Soils.}

In connection with investigations on the organic nitrogen of Hawaiian soils, some study has been made on the effects produced by heat.

Nitrate and Ammonia.-A number of soils representing different types common to Hawaii were subjected to definite temperatures by heating Ioo gram portions in procelain dishes in an air bath for two hours. Steam heat at two atmospheres pressure was also applied. The nitrates were determined by the phenol-sulfonic acid method, and ammonia by direct distillation after adding magnesium oxide. It should be remembered that a portion of the ammonia thus obtained probably occurred in the soils, especially after heating, as amides, rather than ammonium compounds, but, in view of the difficulties in separating amide from ammonia nitrogen in soils, the data will be referred to in this paper as ammonia.

Of the soils studied, No. 9 is a silty soil, containing large amounts of manganese dioxide; No. 290 is a heavy clay soil; Nos. 292 and 407 are clay loams containing considerable gravel; No. 335 is composed very largely of coral sand $\left(\mathrm{CaCO}_{3}\right)$ with only small amounts of organic matter; and No. $4 \mathrm{II}$ is a silty soil containing large amounts of humus.

The data below show that the nitrates of soils undergo decomposition with heating, gradually disappearing as the temperature increases. At $100^{\circ}$ only slight decomposition took place; at $150^{\circ}$ considerable decomposition was produced; while heating to $200^{\circ}$ caused almost complete decomposition of nitrate. Steam heating at a pressure of two atmospheres produced effects similar to those that took place from heating to $150^{\circ}$ without pressure.

\footnotetext{
${ }^{1} J$. Ind. Eng. Chem., 3, 657-60 (1911).

${ }^{2}$ U. S. D. A., Bur. of Soils, Bull. 89 (IgI2).
} 
The EFfects of Heat on the Nitrate and Ammonia Content of Solls.

(Expressed in Percentages of Total Nitrogen.)

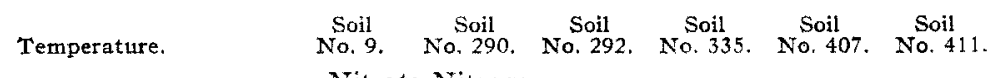
Nitrate Nitrogen.

\begin{tabular}{|c|c|c|c|c|c|}
\hline$\ldots \ldots \ldots \ldots 2.89$ & 0.95 & I. 17 & 0.21 & 0.02 & I. 02 \\
\hline$\ldots \ldots 2.54$ & 0.98 & 0.87 & 0.12 & 0.02 & I.09 \\
\hline . I . 53 & 0.66 & I. $5^{6}$ & 0.19 & 0.01 & 0.03 \\
\hline 0.13 & 0.34 & 0.23 & 0.04 & 0.01 & 0.03 \\
\hline $250^{\circ} \ldots \ldots \ldots$ & 0.03 & 0.09 & 0.06 & 0.01 & $0.0 \mathrm{~T}$ \\
\hline Steam, 2 atmospheres pressure. . 2.52 & 0.55 & 0.83 & 0.06 & 0.02 & 0.87 \\
\hline
\end{tabular}

Ammonia Nitrogen.

\begin{tabular}{|c|c|c|c|c|c|}
\hline$\ldots \ldots \ldots \ldots \ldots \ldots$ & 0.95 & 0.75 & 0.79 & 0.22 & 0.36 \\
\hline$\ldots 0.64$ & 1.03 & 0.70 & I. 14 & 0.33 & $0.5 \mathrm{I}$ \\
\hline$\ldots \quad 1.80$ & $2 \cdot 43$ & 2.15 & 1.09 & 0.70 & I .4 I \\
\hline $200^{\circ}$. & $24 \cdot 46$ & II .62 & 2.14 & 8.98 & 3. II \\
\hline$\ldots \quad 1.09$ & 10.87 & 22.40 & I. 22 & 2.80 & I. 78 \\
\hline Steam, 2 atmospheres pressure... 2.23 & 2.69 & I. I 2 & I. OI & I. 13 & I. 26 \\
\hline
\end{tabular}

Heating to $100^{\circ}$ produced but little effect on the ammonia content. At $150^{\circ}$ considerable increases in ammonia were observed, and in passing from $150^{\circ}$ to $200^{\circ}$ very large increases took place, followed, in every instance except one, by notable decreases at $250^{\circ}$. The falling off in the ammonia content at the higher temperature was no doubt due to the expulsion of the products of decomposition from the soil mass. Steam heating at two atmospheres' pressure split off practically the same amounts of ammonia as dry heat at $150^{\circ}$ without pressure. The nitrogen compounds of soils, therefore, undergo decomposition with heating, and among the products formed those which yield ammonia upon distillation with magnesium oxide are produced in notable amounts.

The organic nitrogen groups, both before and after heating, were determined by the use of the method of acid hydrolysis as outlined in the previous paper. In this way it was hoped to determine the effects produced on the different groups of nitrogen compounds, and indirectly throw some light on the nature of bacterial action in soils. Since heating to $200^{\circ}$ led to the greatest accumulation of ammonia, this temperature was employed. The data obtained from five different soils are submitted in the following table. ${ }^{1}$

Considering first the soils before heating, it will be seen that the percentage of the different groups of nitrogen bodies dissolved by hydrochloric acid varied considerably. Expressing these results in percentages of the total nitrogen dissolved, the non-basic nitrogen on the average equalled $63.82 \%$, the amide $24.21 \%$, and the basic nitrogen $10.13 \%$. The ammonia

1 The data submitted in this table vary slightly from those recorded in the previous paper, and bearing the same lab. no. This is due to different samples of the same soil having been used. 
was determined previous to treating with hydrochloric acid, and by calculation was found to equal $1.81 \%$ of the nitrogen dissolved.

\begin{tabular}{|c|c|c|c|c|c|c|c|c|c|c|c|}
\hline & \multicolumn{2}{|c|}{ EFFECTS 0} & \multicolumn{9}{|c|}{ Soluble in hydrochloric acid. } \\
\hline & \multirow{2}{*}{ 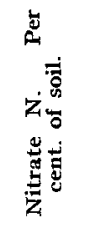 } & \multirow{2}{*}{ 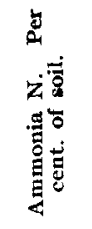 } & \multicolumn{3}{|c|}{ Per cent. of soil. } & \multicolumn{2}{|c|}{ Total. } & \multicolumn{4}{|c|}{ Per cent. of nitrogen in solution. } \\
\hline & & & 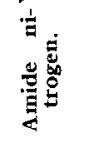 & 总 & 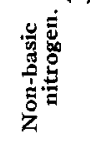 & 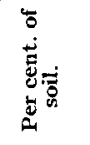 & 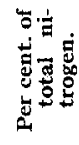 & 离 & 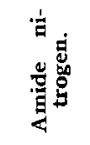 & 总 & 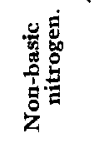 \\
\hline \multicolumn{12}{|c|}{ Before Heating. } \\
\hline 54 & DOI & $0.00 \mathrm{I}$ & 0.096 & 0.030 & 0.29 & 426 & 78.02 & 0.23 & 22.53 & 7.04 & 70 \\
\hline o. & 0.005 & 0.022 & 0.129 & 0.029 & 0.378 & 0.558 & $7 \pi .63$ & $3 \cdot 94$ & 23.12 & 5.09 & 67 \\
\hline 0.396 & 0.006 & 0.001 & 0.074 & 0.033 & 0.131 & 0.239 & 60.35 & $0.4 \mathrm{I}$ & 30.96 & $13.8 \mathrm{I}$ & \\
\hline 0.179 & Trace & 0.005 & 0.042 & 0.019 & 0.099 & 0.165 & 92.18 & 3.03 & $25 \cdot 45$ & II 5 I & \\
\hline & 2 & 0.006 & 0.079 & 0.055 & 0.276 & 0.416 & 82.54 & I. 44 & 18.99 & 13.22 & 66.35 \\
\hline & & & 0.084 & 0.033 & 0.237 & $0.36 \mathrm{I}$ & 76.94 & I. 8I & $24.2 \mathrm{I}$ & IO. I3 & 63.82 \\
\hline
\end{tabular}

After Heating $\left(200^{\circ}\right)$.

$\begin{array}{llllllllllllllll}379 & 0.417 & 0.0 & 0.069 & 0.098 & 0.034 & 0.168 & 0.369 & 88.49 & \text { I } 8.69 & 26.56 & 9.2 \mathrm{I} & 45.53\end{array}$

$\begin{array}{lllllllllllllll}428 & 0.608 & 0.0 & 0.031 & 0.077 & 0.023 & 0.079 & 0.210 & 34.54 & 14.76 & 36.66 & 10.95 & 37.62\end{array}$

$\begin{array}{llllllllllllllll}447 & 0.207 & 0.0 & 0.020 & 0.039 & 0.022 & 0.028 & 0.109 & 52.66 & \text { I } 8.35 & 35.78 & \text { 10. } 18 & 25.69\end{array}$

$\begin{array}{llllllllllllll}405 & 0.178 & 0.0 & 0.036 & 0.056 & 0.019 & 0.041 & 0.152 & 85.39 & 23.68 & 36.84 & 12.50 & 26.97\end{array}$

$\begin{array}{llllllllllllll}406 & 0.419 & 0.0 & 0.067 & 0.103 & 0.019 & 0.092 & 0.281 & 67.06 & 23.84 & 35.65 & 6.76 & 32.74\end{array}$

$\begin{array}{lllllllllllllll}\text { Av. } 0.366 & 0.0 & 0.045 & 0.075 & 0.023 & 0.082 & 0.224 & 65.63 & \text { I } 9.86 & 34.50 & \text { II.92 } & 33.7 \text { I }\end{array}$

Upon heating notable changes took place; the ammonia increased from $0.007 \%$ to $0.045 \%$ of the moisture free soil, or from $1.81 \%$ to $19.86 \%$ of the nitrogen dissolved. The amounts of amide nitrogen in soils 428 and 447 were considerably reduced by heating, while those of soils 405 and 406 were slightly increased. In no instance, save soil No. 406, was there any notable change in the amount of basic nitrogen. On the average then, heat effected but little change in the amounts of amide and basic nitrogen present. Considering the non-basic nitrogen, on the other hand, notable losses were sustained from the heating.

The loss of nitrogen amounted, on the average, to approximately $25 \%$, but in this respect considerable difference was observed in the different soils. Soil No. 447 suffered the heaviest loss, amounting almost to $50 \%$, while the loss from No. 405 was within the limits of experimental error. Heating to $200^{\circ}$ for two hours, therefore, caused a loss of nitrogen and the formation of large amounts of ammonia, which nitrogen came largely from the complexes that yield non-basic nitrogen upon acid hydrolysis.

In the previous paper some of the striking differences between soil nitrogen and that of the vegetable proteins were pointed out. It was shown, for example, that the nitrogen bodies split off from soil organic matter by boiling hydrochloric acid were made up of relatively greater amounts of amide, and correspondingly smaller amounts of basic nitro- 
gen, than occur in the vegetable proteins. To account for this it was suggested that bacterial action probably causes a more marked splitting off of the basic nitrogen constituents, than of the other groups, at least in the early stages of the decomposition.

On the other hand it is shown in the present paper, that heat causes a breaking up of the organic nitrogen bodies in such a way as to liberate large amounts of ammonia from the antecedents of the non-basic nitrogen bodies-presumbaly the mono-amino acids.

Honolulu, hawair.

\section{THE ORGANIC NITROGEN OF HAWAIIAN SOILS. ${ }^{1}$ III. THE NITROGEN OF HUMUS.}

BY W. P. KELLEY AND ALICH R. THOMPSON.

Received December 15, 1913.

Introduction.

That part of the organic matter of soils soluble in dilute alkali, and known as humus, is generally considered to exert special influence on fertility. Moreover, it is claimed that the nitrogen contained in humus becomes available more readily than non-humus nitrogen. Dr. Hilgard found, ${ }^{2}$ for instance, that during the first four months after extracting the humus from a soil, no nitrification took place, although the nonhumus nitrogen in the soil amounted to $0.127 \%$; after the lapse of two years' time an insignificant amount of nitrate was formed, whereas vigorous nitrification took place in the original soil. The fact that no nitrate was formed from the non-humus nitrogen until after several months' time, and then only at a very slow rate, suggests that the alkali-soluble nitrogen existed in different forms from the non-humus nitrogen. It should be borne in mind, however, that other factors than those having to do with the chemical nature of the nitrogen bodies also exert important influence on bacterial action, such factors as the food supply available to the bacteria, and the physical, chemical and biological conditions, all of which probably underwent some change as a result of extracting the humus.

The general interest taken in soil humus justifies some investigation on the nitrogen bodies contained. The so-called humification process has been the subject of much speculation for many years, but it must be admitted that very little definite knowledge exists regarding the chemistry involved in this process. Bacteria undoubtedly bring about manifold chemical changes in the organic matter, causing it to pass through varying degrees of decomposition leading up to the formation of humus, but regarding the transformations the nitrogen bodies undergo in this process little is known.

1 Contribution from the Hawaii Agricultural Experiment Station.

2 Soils, pp. 358-60. 